\title{
Formation Tools of Financial Strategy for the Development of Agricultural Organizations
}

\author{
Zaporozhtseva L.* \\ Department of Finance and Credit \\ Voronezh State Agrarian University named after Emperor \\ Peter the Great \\ Voronezh, Russia \\ LUDAN23@yandex.ru \\ Malitskaya V. \\ Department of Accounting and Taxation \\ Plekhanov Russian University of Economics \\ Moscow, Russia \\ vmrussian@yandex.ru
}

\author{
Tkacheva Yu. \\ Department of Finance and Credit \\ Voronezh State Agrarian University named after Emperor \\ Peter the Great \\ Voronezh, Russia \\ julchen19@yandex.ru \\ Shishkina L. \\ Department of Economic Analysis, Statistics and Applied \\ Mathematics \\ Voronezh State Agrarian University named after Emperor \\ Peter the Great \\ Voronezh, Russia \\ kz2009kzaf@gmail.com
}

\author{
Popov D. \\ Department of Farm Production Management and \\ Entrepreneurial Business in Agro-Industrial Complex \\ Voronezh State Agrarian University named after Emperor Peter the Great \\ Voronezh, Russia \\ organiz@agroeco.vsau.ru
}

\begin{abstract}
Despite the large number of tools available in the literature for strategic management of enterprises, changes in business conditions and success criteria create a need for highly specialized point methods and methods. The article discusses the developed matrix of financial strategy for the development of commercial organizations, based on the calculation of the economic value added indicator (EVA) and the indicator of the managed and critical debt load according to the Debit/EBITDA criterion. The author's model is able to take into account the possibilities of "healthy" functioning of the enterprise in conditions of creation or destruction of value at different levels of debt load. The matrix has 4 quadrants. Organizations falling into the upper quadrants of the matrix use a financial development strategy (moderate or aggressive). Organizations occupying lower quadrants are not developing, but, on the contrary, stagnating. Therefore, in order for the enterprise to get on the path of development, it is necessary to adjust the financial strategy so that it can occupy one of the upper quadrants. This methodology was tested at agricultural organizations. Examples of organizations falling into different quadrants of the matrix, problems and advantages of the situation are considered and financial strategies for their development are formed.
\end{abstract}

Keywords - financial strategy, development matrix, commercial organizations, agriculture.

\section{INTRODUCTION}

Agriculture is an important dynamic sector of the economy. Many students tend to be specific to its functioning, expressed in the need to focus on biological factors, technology and financing. Others do not highlight significant differences by highlighting the overall business process architecture that is common to any business. Immutable for both the former and the latter is the fact that the purpose of commercial activity is to generate profit, so corporations are created for the sake of its long-term, stable generation. However, business conditions are constantly changing, accompanied by an increase in crises and rapid changes in economic development.

The concept of strategic management reflects the clear strategic positioning of the enterprise (including its financial position). It is presented in the system of principles and objectives of its functioning, the mechanism of interaction between the subject and the object of management, the nature of the relationship between the elements of the economic and organizational structure and the forms of their adaptation to the changing conditions of the external environment.

\section{RATIONALE FOR FINANCIAL STRATEGY OF ENTERPRISE DEVELOPMENT}

Modern foreign research in the field of strategic management of corporate finance focuses on the formation of a breakthrough strategy of enterprise financial management in the era of network economy (J. Ma [9]), the creation of a managed blockchain model of ecosystem for enterprise financial management (Q. Liu, Y.K. Song [7]), the impact of 
strategic enterprise risk management on competitive advantage by mitigating the role of information technologies (Saeidi P. et al. [13]), etc.

It is necessary to note that such a need in our country also exists along with the change of strategic goal from sustainability to ensuring the development of the organization [1].

In implementing the financial strategy, according to E.S. Palyan [12], attention should be paid to the following criteria of its effectiveness:

- ensuring development of an institutional and personnel basis of activity of firm at various stages of implementation of points of the developed plans;

- providing effective mechanisms of control over the solution of objectives;

- timely analytics of the achieved results.

From the position of S. N. Gnatiuk, L.I. Pushkin [3], the financial strategy of the enterprise development should be embedded in the overall strategy of the enterprise as a whole. It systematizes the factors, prerequisites and activities on which the development of the enterprise depends and makes it possible to interpret the problem and activities to ensure the required level of development [14].

In the market environment, healthy functioning of commercial organizations is possible when planning their development in the strategic perspective. The category "financial strategy" has economic justification of content and characteristic methods of development. In turn, the concept of "healthy" development of a commercial organization is relatively new.

At the same time, the main goal of the financial strategy is both to ensure the well-being of owners and to achieve sustainability, sustainable development or safety of the enterprise [4]. Depending on the choice give the name and the developed financial strategy.

For example, the financial strategy of sustainable development of commercial organizations T.V. Kasayev, E.S. Georgian [6] is interpreted as a set of three interrelated key components: economic, environmental and social, reflected through the growth of financial indicators.

The strategy of ensuring financial security of L.A. Zaporozhtseva [17] defines as one of the types of functional strategy of the enterprise, ensuring its growth and protection of financial interests against various threats by forming long-term directions of development.

\section{METHODS AND METHODOLOGY FOR DEVELOPING A FINANCIAL STRATEGY FOR ENTERPRISE DEVELOPMENT.}

In order to develop the development strategy of the commercial organization N.A. Nikolayeva, D.I. Ipipova [11] proposes to use such methods as SWOT and PEST-analysis. SWOT-analysis is a method of strategic planning, which allows determining the influence of factors of internal and external environment of the organization. The PEST-analysis allows identifying and evaluating significant factors of the external environment of the enterprise that may affect its activities in the future. The results of the PEST-analysis are applicable as a basis for SWOT analysis.

Science has proposed other models for forming a financial strategy for the development of the enterprise, such as the model of J. Franchon and I. Roman, the matrix model of I.J. Lukasevich [8], the model of Dupont (DuPont), the "golden rule of economics" and others [2], [5],[15].

\section{MATERIALS FOR THE DEVELOPMENT OF A FinANCIAL STRATEGY FOR THE DEVELOPMENT OF ENTERPRISES}

To identify the problems of developing a methodology for forming a financial strategy for the development of commercial organizations, we partially tested them on the data of enterprises in the real sector of the economy of one industry and territory. Based on the calculations presented in table 1, we will assess the development of agricultural organizations in the Liskinsky district in 2017, based on the fulfillment of the "golden rule of the economy" condition. It has been established that only $30 \%$ of the total number of agricultural organizations in the Liskinsky district fulfill the conditions of the "golden rule of the economy". That is, only JSC "9-ya Pyatiletka", OJSC "Mayak" and LLC "LISKo Broiler" are steadily developing.

TABLE I. ASSESSMENT OF IMPLEMENTATION OF THE "GOLDEN RULE OF ECONOMY" BY AGRICULTURAL ORGANIZATIONS IN THE LISKINSKY DISTRICT IN 2017

\begin{tabular}{|l|c|c|c|c|}
\hline \multirow{2}{*}{$\begin{array}{c}\text { Agricultural } \\
\text { Organizations }\end{array}$} & \multicolumn{3}{|c|}{ Growth Rate,\% } & $\begin{array}{c}\text { Rule } \\
\text { Compliance, } \\
\text { yes/no }\end{array}$ \\
\cline { 2 - 4 } & 2000.5 & 114.8 & 106.6 & Yes \\
\hline JSC "9-ya Pyatiletka" & 53.5 & 106.3 & 110.3 & No \\
\hline JSC "Troitskoye" & 593.8 & 118.3 & 107.4 & Yes \\
\hline OJSC "Mayak" & 34.8 & 116.3 & 105.1 & No \\
\hline LLC "Yermolovskoe" & 64.0 & 96.6 & 114.6 & No \\
\hline LLC "imeni Tel'mana" & 37.1 & 190.8 & 144.4 & No \\
\hline LLC "Lisky Sad" & 706.2 & 110.9 & 116.6 & Yes \\
\hline LLC "LISKO Broiler" & 71.4 & 141.5 & 4800.6 & No \\
\hline LLC "TD Ptitsa" & 149.8 & 108.4 & 137.8 & No \\
\hline LLC "EkoNivaAgro" & 89.1 & 105.9 & 108.2 & No \\
\hline APC "Liskisnkiy" & & & & \\
\hline
\end{tabular}

Next, we assessed the financial independence of these same organizations, using the autonomy coefficient, calculated as the ratio of equity to the balance sheet currency (Table 2).

According to the calculations presented in Table 2, the $60 \%$ of the total number of agricultural organizations of Liskin district are financially independent.

Taking into account the opinion of E.V. Rogatenyuk [16], we propose to consider one of the main characteristics of the "health" of the enterprise, the existence and amount of debt. At the same time, it should be stressed that it is not possible to assess financial "health" on the basis of this approach, as we have identified the existence of obligations, the effect of their attraction, but the possibility of their repayment has not been determined (Table 3). 
TABLE II. ASSESSMENT OF FINANCIAL INDEPENDENCE OF AGRICULTURAL ORGANIZATIONS IN THE LISKINSKY DISTRICT

\begin{tabular}{|l|c|c|c|}
\hline \multirow{2}{*}{ Agricultural Organizations } & \multicolumn{2}{|c|}{ Periods } & $\begin{array}{c}\text { Rule } \\
\text { Compliance, } \\
\text { yes/no }\end{array}$ \\
\cline { 2 - 4 } & $\mathbf{2 0 1 6}$ & $\mathbf{2 0 1 7}$ & Yes \\
\hline JSC "9-ya Pyatiletka" & 0.59 & 0.63 & Yes \\
\hline JSC "Troitskoye" & 0.88 & 0.89 & Yes \\
\hline OJSC "Mayak" & 0.53 & 0.50 & Yes \\
\hline LLC "Yermolovskoe" & 0.81 & 0.82 & Yes \\
\hline LLC "imeni Tel'mana" & 0.88 & 0.96 & No \\
\hline LLC "Lisky Sad" & 0.16 & 0.19 & No \\
\hline LLC "LISKo Broiler" & 0.39 & 0.42 & No \\
\hline LLC "TD Ptitsa" & 0.02 & 0.98 & No \\
\hline LLC "EkoNivaAgro" & 0.22 & 0.25 & Yes \\
\hline APC "Liskinskiy" & 0.91 & 0.88 & a. by autonomy ratio \\
\hline
\end{tabular}

TABLE III. EBITDA AND DEBT INDICATORS OF AGRICULTURAL ORGANIZATIONS IN THE LISKINSKY DISTRICT

\begin{tabular}{|l|c|c|c|c|}
\hline \multirow{2}{*}{$\begin{array}{c}\text { Agricultural } \\
\text { Organizations }\end{array}$} & \multicolumn{2}{|c|}{ Debt, RUR thousand } & \multicolumn{2}{c|}{$\begin{array}{c}\text { EBITDA, RUR } \\
\text { thousand }\end{array}$} \\
\cline { 2 - 5 } & $\mathbf{2 0 1 7}$ & $\mathbf{2 0 1 6}$ & $\mathbf{2 0 1 7}$ & $\mathbf{2 0 1 6}$ \\
\hline JSC "9-ya Pyatiletka" & 132371 & 23040 & 28783 & 19534 \\
\hline JSC "Troitskoye" & 25941 & 742819 & 30426 & 45322 \\
\hline OJSC "Mayak" & 739396 & 45474 & 229421 & 140488 \\
\hline LLC "Yermolovskoe" & 49966 & 5370 & 35647 & 40840 \\
\hline LLC "imeni Tel'mana" & 17856 & 40726 & 24852 & 32555 \\
\hline LLC "Lisky Sad" & 61126 & 4446504 & 3836 & 6374 \\
\hline LLC "LISKO Broiler" & 5485988 & 42 & 2028704 & 844998 \\
\hline LLC "TD Ptitsa" & 103857 & 10946072 & 4313 & 1863 \\
\hline LLC "EkoNivaAgro" & 15750307 & 83809 & 2990786 & 2385614 \\
\hline APC "Liskisnkiy" & 66765 & 0 & 125144 & 143968 \\
\hline
\end{tabular}

But, as practice shows, it is not so much the size of the debt, the maturity, as the ratio of it to the supporting characteristics, for example, EBITDA (1), that is importan:

$$
\mathrm{EBITDA}=\mathrm{NI}+\mathrm{I}+\mathrm{T}+\mathrm{D}+\mathrm{A}
$$

where NT - Net Income, I - Interest, T - Taxes, D Depreciation, A- Amortization.

EBITDA shows the financial result of the enterprise, excluding the impact of the effect of the capital structure, that is, the interest that is paid on the borrowed funds [10]

At the same time, in our opinion, the Debt/EBITDA indicator should be used in order to estimate the debt burden of the agricultural organizations of Liskin district compared to its fair EBITDA profit.

The use of the Debt/EBITDA multiplier is justified and necessary to identify the ability of the organization to pay its debt and determine the period of its repayment. This is due to the fact that in the numerator of this indicator there is the amount of debt accumulated by the enterprise, in the denominator - the value of "fair" profit (excluding taxes, interest and depreciation).
As a result, private is the number of years a business needs to generate a profit sufficient to repay existing debts.

From the management point of view, it is effective to have a minimum value of this indicator, as the lower the Debit/EBITDA multiplier, the lower the debt burden of the organization, and therefore the lower the risk of loss of solvency and the appearance of signs of bankruptcy. At the same time, Debt/EBITDA, an increasing multiplier in dynamics, is also a dangerous signal that the company 's debts are growing faster than its profits.

The high Debt/EBITDA has a negative impact on the dividend policy of the organization. This is because the more debt the company has, the more expensive the cost of servicing it. So the company will have to pay more money in the form of interest, and net profit will be less, and with it dividends.

We calculated and presented in Table 4 the Debt/EBITDA ratio as a key indicator of "business health," the value of $4-5$ units is considered already critical for evaluation.

TABLE IV. DEBT/EBITDA INDICATORS OF AGRICULTURAL ORGANIZATIONS IN THE LISKINSKY DISTRICT

\begin{tabular}{|l|c|c|}
\hline \multirow{2}{*}{\multicolumn{1}{|c|}{ Agricultural Organizations }} & \multicolumn{2}{c|}{ Debt/ EBITDA } \\
\cline { 2 - 3 } & $\mathbf{2 0 1 7}$ & $\mathbf{2 0 1 6}$ \\
\hline JSC "9-ya Pyatiletka" & 4.6 & 1.2 \\
\hline JSC "Troitskoye" & 0.9 & 16.4 \\
\hline OJSC "Mayak" & 3.2 & 0.3 \\
\hline LLC "Yermolovskoe" & 1.4 & 0.1 \\
\hline LLC "imeni Tel'mana" & 0.7 & 1.3 \\
\hline LLC "Lisky Sad" & 15.9 & 697.6 \\
\hline LLC "LISKO Broiler" & 2.7 & 0.0 \\
\hline LLC "TD Ptitsa" & 24.1 & 5875.5 \\
\hline LLC "EkoNivaAgro" & 5.3 & 0.0 \\
\hline APC "Liskisnkiy" & 0.5 & 0.0 \\
\hline
\end{tabular}

According to Table 4, four agricultural organizations in the Liskinsky district have a critical level of debt: JSC "9-ya Pyatiletka", LLC "Lisky Sad", LLC "TD Ptitsa" and LLC "EkoNivaAgro". At the same time, as we can see, the assessment of the financial independence of agricultural organizations in the Liski district by the coefficient of autonomy does not fully reveal this problem. Organizations that are able to pay off their debts (for example, LLC "Lisko broiler") are considered financially independent and organizations that have a critical level of debt (for example, JSC "9th five-year plan") are considered financially independent. The assessment of the implementation of the "Golden rule of Economics" by agricultural organizations in the Liskinsky district does not reflect the full picture of development.

In this regard, we believe it is advisable to use the Debit/EBITDA indicator as a ratio of debt burden of agricultural organizations to fair profit in order to form a financial strategy for the development of commercial organizations. 


\section{RESUlts}

As a result, a financial strategy for the development of a commercial organization is proposed to mean a system of long-term financial objectives, as well as a choice of development options that increase the potential and cost of business with available resources, taking into account trends in the influence of internal and external destabilizing factors.

In developing the methodology for the formation of a financial strategy for the development of commercial organizations, we modified the matrix based on the model of sustainable growth and the internal growth rate of the enterprise (I.J. Lukasevich,[8]), which is based on the calculation of Economic Value Added (EVA). For this purpose, we will replace the condition of the ratio of sustainable growth factors to internal growth with the indicator of managed and critical debt load according to the Debit/EBITDA criterion. In this way the matrix will be able to take into account the possibilities of "healthy" development of the enterprise in the following pattern:

- The lower the Debit/EBITDA multiplier, the less the debt burden of the organization, and therefore the ower the risk of loss of solvency and signs of bankruptcy;

- Debt/EBITDA 's high multiplier (more than 4) is a dangerous signal that the company 's debts are growing faster than its profits;

- $\quad$ EVA provides a comprehensive description of business development - value creation or destruction. However, this indicator reflects the cost of the business.

Our proposed matrix of financial strategy for development of commercial organizations is shown in Fig. 1.

Commercial organizations falling into the right upper quadrant of the matrix prefer a strategy of aggressive development mainly at the expense of borrowed sources of financing. The management of these firms should adhere to a financial strategy that implies development not only through borrowed sources, but also through the maximization of net profit and its capitalization. Such companies should increase the rate of production and sale of products, use available capital more effectively, reduce liabilities. This will be particularly justified if rapid growth is essential to achieving strategic competitive advantage and the return on investment exceeds capital costs.

Enterprises belonging to the right upper quadrant of the matrix are profitable firms operating in high-level sectors of the economy, with limited growth opportunities due to strong competition, as well as rich market demand. They choose a strategy of moderate development mainly at the expense of their own sources of financing, In this case, management should use opportunities for growth in terms of implementation of new projects, purchase of existing enterprises, or allocate funds for payment to owners.

Firms falling into the right lower quadrant of the matrix have a critical level of debt burden, at which they are unable to further repay their financial obligations. At the same time, the cost of such organizations is being destroyed. In this case, the management of the organization needs to change the strategy, restructure the business, re-engineer all business processes. The last measure of the way out of such a situation is the sale of the business or the corresponding division.

\begin{tabular}{|c|c|c|}
\hline $\begin{array}{l}\text { Take advantage of } \\
\text { opportunities for growth: } \\
\text { implementation of new } \\
\text { projects, purchase of } \\
\text { existing enterprises. } \\
\text { Allocate funds for } \\
\text { payment to owners. }\end{array}$ & 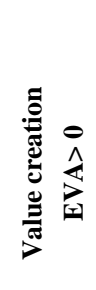 & $\begin{array}{l}\text { Increase the rate of } \\
\text { production and sale } \\
\text { of products. Make } \\
\text { better use of } \\
\text { available capital. To } \\
\text { reduce the volume of } \\
\text { obligations }\end{array}$ \\
\hline $\begin{array}{c}\text { The operated debt load } \\
\text { Debt/EBITDA }<4\end{array}$ & & $\begin{array}{c}\text { Critical Debt Burden } \\
\text { Debt/ EBITDA } \geq 4\end{array}$ \\
\hline $\begin{array}{l}\text { Focus on improving } \\
\text { profitability. } \\
\text { Review the structure of } \\
\text { capital, achieve a } \\
\text { reduction in its value. If } \\
\text { the measures taken do } \\
\text { not have an effect, go } \\
\text { out of business. }\end{array}$ & 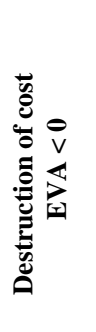 & $\begin{array}{l}\text { Change strategy, } \\
\text { restructure business. } \\
\text { Re-engineering all } \\
\text { business processes. } \\
\text { If the measures taken } \\
\text { do not have an } \\
\text { effect, go out of } \\
\text { business. }\end{array}$ \\
\hline
\end{tabular}

Fig. 1. Matrix of Financial Strategies for the Development of Commercial Organizations

Lower-left quadrant firms do not have the capacity to expand their operations and at the same time have low profitability. Such organizations are in the process of destroying value at a low level of obligations. The financial strategy of such firms should be aimed at improving the profitability of the business, reviewing the structure of capital, reducing its cost. As in the previous situation, the last measure is to exit the "dying" business and switch to new activities.

We tested the matrix of financial strategy developed by us for the development of commercial organizations according to the data of APC "Liskisnkiy" for 2017-2019. Calculations are presented in Table 5.

As a result of the calculations, we have found that APC "Liskisnkiy" has occupied the left upper square of the matrix for the last three years, and therefore uses a strategy of moderate development mainly at the expense of its own sources of financing. From our position, the management of APC "Liskisnkiy" has properly formed a financial strategy, it makes no sense to change it, but it is necessary to use additional opportunities for growth and reduction of obligations. This concerns the application of financial management techniques to estimate the directions of profit increase, which in the future can be both capitalized and allocated for payment to owners.

The expediency of increasing profit and profitability is also indicated by the dynamics of key indicators - economic value added is decreasing, and the ratio of liabilities to fair profit is increasing. 
TABLE V. CALCULATION OF INDICATORS FOR DETERMINING THE POSITION OF APC "LISKISNKIY"ON THE MATRIX OF FINANCIAL STRATEGY FOR DEVELOPMENT OF COMMERCIAL ORGANIZATIONS

\begin{tabular}{|c|c|c|c|}
\hline \multirow{2}{*}{ Indicators } & \multicolumn{3}{|c|}{ Periods } \\
\hline & 2017 & 2018 & 2019 \\
\hline Debt, RUR thousand & 66765 & 77533 & 152070 \\
\hline EBITDA, RUR thousand & 125144 & 102973 & 108068 \\
\hline Debt/ EBITDA & 0.5 & 0.8 & 1.4 \\
\hline $\begin{array}{l}\text { Net Operating Profit } \\
\text { After Tax (NOPAT), } \\
\text { RUR thousand }\end{array}$ & 103082 & 79286 & 84017 \\
\hline $\begin{array}{l}\text { Invested Capital (IC), } \\
\text { RUR thousand }\end{array}$ & 659739 & 712420 & 767323 \\
\hline $\begin{array}{l}\text { Weight average cost of } \\
\text { capital (WACC), } \%\end{array}$ & 4.24 & 3.37 & 3.17 \\
\hline $\begin{array}{l}\text { Economic Value Added } \\
\text { (EVA), RUR thousand }\end{array}$ & 75122 & 55292 & 59719 \\
\hline & $\begin{array}{l}\text { Upper left } \\
\text { quadrant }\end{array}$ & $\begin{array}{l}\text { Upper left } \\
\text { quadrant }\end{array}$ & $\begin{array}{l}\text { Upper left } \\
\text { quadrant }\end{array}$ \\
\hline Position on the matrix & $\begin{array}{l}\text { EVA }>0 \\
\text { Debt/ } \\
\text { EBITDA }<4\end{array}$ & $\begin{array}{l}\text { EVA }>0 \\
\text { Debt/ } \\
\text { EBITDA }<4\end{array}$ & $\begin{array}{l}\text { EVA }>0 \\
\text { Debt/ } \\
\text { EBITDA }<4\end{array}$ \\
\hline
\end{tabular}

We tested the matrix of financial strategy developed by us for the development of commercial organizations on the example of agricultural enterprises of the Voronezh region. By random sampling we selected 30 agricultural enterprises for which model indicators were calculated according to the data for 2018. As a result, among the typical enterprises were APC "Liskisnkiy" and LLC "Eco NivaAgro" of Liskinsky district, LLC MC "Agroculture" of Voronezh, as well as FSUE "Vorobevskoe" Vorobievsky district of the Voronezh region. The calculations are shown in Table 6.

Thus, as we have already noted above, APC "Liskisnkiy" occupies the left upper square of the matrix and thus uses a strategy of moderate development.

LLC "EcoNivaAgro" meets a condition (EVA>0 and Debt/EBITDA $\geq 4$ ) and uses the strategy of aggressive development mainly at the expense of loan sources of financing, occupying the upper right quadrant of a matrix. LLC "Eco NivaAgro" should increase the rate of production and sale of products, more efficiently use the available capital, reduce the volume of liabilities.

FSUE "Vorobevskoye" appeared in the worst state (EVA $<0$ and Debt/EBITDA $\geq 4$ ), occupied the lower right quadrant of a matrix, does not develop, has the critical level of a debt load at which it is not able to repay the undertaken financial obligations independently further. At the same time, the value of the organization is destroyed. In this case, the management of the organization needs to change the strategy, restructure the business, reengineering all business processes, which is extremely difficult in agriculture. Apparently, the way out of this situation will be to sell the business.

LLC MC "Agroculture" meets the requirement of the lower left quadrant of the matrix. The organization found value destruction at a low level of liabilities. The financial strategy of LLC MC "Agroculture" should be aimed at increasing the profitability of the business, reviewing the structure of capital, reducing its cost.
TABLE VI. CALCULATION OF INDICATORS FOR DETERMINING THE POSITION OF APC "LISKISNKIY"ON THE MATRIX OF FINANCIAL STRATEGY FOR DEVELOPMENT OF COMMERCIAL ORGANIZATIONS

\begin{tabular}{|c|c|c|c|}
\hline \multirow[b]{2}{*}{ Indicators } & \multicolumn{3}{|c|}{ Enterprises } \\
\hline & $\begin{array}{c}\text { LLC } \\
\text { "EcoNivaAgro" }\end{array}$ & $\begin{array}{c}F S U E \\
\text { "Vorobevskoye" }\end{array}$ & $\begin{array}{c}\text { LLC MC } \\
\text { "Agroculture" }\end{array}$ \\
\hline $\begin{array}{l}\text { Debt, RUR } \\
\text { thousand }\end{array}$ & 30408557 & 35322 & 1395858 \\
\hline $\begin{array}{l}\text { EBITDA, } \\
\text { RUR } \\
\text { thousand }\end{array}$ & 3012819 & 7725 & 1203050 \\
\hline $\begin{array}{l}\text { Debt/ } \\
\text { EBITDA }\end{array}$ & 10.1 & 4.57 & 1.16 \\
\hline $\begin{array}{l}\text { Net Operating } \\
\text { Profit After } \\
\text { Tax } \\
\text { (NOPAT), } \\
\text { RUR } \\
\text { thousand }\end{array}$ & 1412852 & 230 & 510814 \\
\hline $\begin{array}{l}\text { Invested } \\
\text { Capital (IC), } \\
\text { RUR } \\
\text { thousand }\end{array}$ & 4673575 & 29320 & 4055540 \\
\hline $\begin{array}{l}\text { Weight } \\
\text { average cost } \\
\text { of capital } \\
\text { (WACC), \% }\end{array}$ & 3.39 & 4.08 & 23.6 \\
\hline $\begin{array}{l}\text { Economic } \\
\text { Value Added } \\
\text { (EVA), RUR } \\
\text { thousand }\end{array}$ & 1254326 & -966 & -702196 \\
\hline \multirow{2}{*}{$\begin{array}{l}\text { Position on } \\
\text { the matrix }\end{array}$} & Upper right quadrant & $\begin{array}{l}\text { Lower right } \\
\text { quadrant }\end{array}$ & $\begin{array}{l}\text { Lower left } \\
\text { quadrant }\end{array}$ \\
\hline & $\begin{array}{l}\text { EVA }>0 \\
\text { Debt/ EBITDA } \geq 4\end{array}$ & $\begin{array}{l}\text { EVA }<0 \\
\text { Debt } / \text { EBITDA } \geq 4\end{array}$ & $\begin{array}{l}\text { EVA }<0 \\
\text { Debt } / \text { EBITDA }<4\end{array}$ \\
\hline
\end{tabular}

\section{CONCLUSIONS}

Thus, the success of the activity is largely determined by the speed and correctness of the enterprise's response to changes in the external and internal environment, where the key factor determining the efficiency of business activity is "business health." Through the example of typical enterprises, we show the feasibility of using the proposed innovative methodology to develop a financial strategy for the development of commercial organizations. The application of quantitative criteria of "business health" will help management to make the necessary financial decisions in time in the strategic perspective.

\section{References}

[1] A.V. Agibalov, Y.V. Tkacheva, L.A. Zaporozhtseva, "Improvement of the financial management strategy for agricultural enterprises", J. of Econ. and Manag. Perspect., vol. 11, no. 3, pp. 1686-1696, 2018.

[2] N.V. Chaikovskaya, I.V. Terentieva, K.A. Lukashova, "Methodical and practical aspects of development of financial strategy of the industrial enterprise", IOP Conf. Ser. Mater. Sci. and Engineer., vol. 537, no. 4, pp. 042-076, 2019.

[3] S.N. Gnatiuk, L.I. Pushkin, "Algorithm of Diagnostics of Sustainable Development of the Enterprise", Coll. of Sci. Works Probl. of Econ., vol. 1, no. 28, pp. 51-65, 2019.

[4] S. Gorlanov, Z. Medelyaeva, V. Malitskaya, M. Chirkova, E. Kostyukova, "Content analysis the term "effectiveness" and the concepts of its quantitative characteristics", Indo Amer. J. of Pharmac. Sci., vol. 06, no. 03, pp. 5293-5298, 2019. 
[5] L. Guryanova, T. Klebanova, T. Trunova, "Modeling the financial strategy of the enterprise in an unstable environment", Econ. Stud., vol. 26, no. 3, 2017.

[6] E.V. Kasayeva, E.S. Georgevich, "Development of a mechanism for evaluating the implementation of the strategy of sustainable development of a commercial organization", J. of Vitebsk State Technol. Univer., vol. 1, no. 26, pp. 196-205, 2014.

[7] Q. Liu, Y.K. Song, "Creating Blockchain Driven Ecosystem Model for Enterprise Financial Management”, pp. 321-326, 2020 [Int. Acad. Conf. on Frontiers in Soc. Sci. and Manag. Innovat. (IAFSM 2019)]. Atlantis Press.

[8] I.J. Lukasevich, Financial management, Textbook. Moscow: Eksmo, 2007, $768 \mathrm{p}$

[9] J. Ma, "Breakthrough Strategy of Enterprise Financial Management in the Era of Network Economy", vol. 4, pp. 301-304, 2019 [Annual Conf. of the Society for Manag. and Econ.]. The Acad. of Engineer. and Ed., 2019.

[10] R.S.A. Makkayeva, H.S.M. Makkayev, "Analysis of EBITDA indicator and its role in determining investment attractiveness of the company", Econ. of Sustainable Development, vol. 40, pp. 219-224, 2019.

[11] N.A. Nikolayeva, D.I. Osipova, "Development of a strategy for the development of a commercial organization", pp. 396-398, 2014 [Coll.
Problems of sustainable development of Russian regions the materials of the All-Russ. Sci. and Pract. Conf. with int. participat., res. ed. L.N. Rudneva]

[12] E.S. Palyan, "Financial Strategy as a Fundamental Element of Strategic Management of Enterprise Finances", J. of Modern Res., vol. 5.4, no. 20, pp. 302-304, 2018.

[13] P. Saeidi et al., "The impact of enterprise risk management on competitive advantage by moderating role of information technology", Computer Standards \& Interfaces, 2019, vol. 63, pp. 67-82.

[14] I. Stolnyk et al., "Theoretical Basis for Improving the Enterprise Financial Condition", Account. and Finance, vol. 3, pp. 107-112, 2019.

[15] R. Tang, C. Li, "Discussion on financial management strategy of group enterprise based on Internet" [3rd Int. Conf. on Econ., Soc. Sci., Arts, Ed. and Manag. Engineer. (ESSAEME 2017)]. Atlantis Press, 2017.

[16] E.V. Rogatenyuk, "On the ratio of" debt security "and" debt sustainability", Sci. of the notes of the Crimean Fed. Univer. named after V.I. Vernadsky, Econ. and Manag., vol. 5(71), no. 2, pp. 91-99, 2019.

[17] L.A. Zaporozhtseva, M.E. Ryabyh, "Development of a strategy for ensuring financial security of the enterprise", Basic res., vol. 11-8, pp. 1637-1642, 2013. 